Full-text Available Online at www.ajol.info and www.bioline.org.br/ja
J. Appl. Sci. Environ. Manage. Sept, 2015

Vol. 19 (3) 397 - 400

\title{
Influence of Pre-germination Treatments on Germination Potentials and Seedling Vigour of Albizia zygia(D.C. Macbr.)
}

\section{YISAU $^{1}$, JA; ADURADOLA ${ }^{2}$, AM; AGBOOLA ${ }^{3}$, DA; JAYEOLA ${ }^{4}$, OA}

Department of Forestry and Wildlife Management, Federal University of Agriculture PMB 2240 Abeokuta Department of Forestry and Wildlife Management, Federal University of Agriculture PMB 2240 Abeokuta mikeadura@yahoo.com

Department of Biological Sciences,, Federal University of Agriculture PMB 2240 Abeokuta agboolada@unaab.edu.ng Department of Forestry and Wildlife Management, Federal University of Agriculture PMB 2240 Abeokuta, tolajayeola@yahoo.com

\begin{abstract}
This study was carried out with the aim of providing basic information on the best pre-treatments in breaking dormancy experienced by Albizia zygia seeds and seedling growth. 120 seeds of Albizia zigia were subjected to mechanical scarification (at three selected points namely: around the circumference, distal and micropyle ends). 120 seeds were pre-treated with hot water at three temperature regimes $\left(20^{\circ} \mathrm{C}, 40^{\circ} \mathrm{C}, 60^{\circ} \mathrm{C}\right)$ for 5,10 and 15 minutes and sulphuric acid $\left(\mathrm{H}_{2} \mathrm{SO}_{4}\right)$ at three levels of concentrations $(10 \%$, $30 \%$, and 50\%) respectively. Data was subjected to descriptive and inferential statistics (both one and two ways analysis of variance). Highest germination percentages were recorded in seeds scarified around the circumference, hot water at $60^{\circ} \mathrm{C}$ for $5 \mathrm{~min}$ and $50 \%$ sulphuric acid for $15 \mathrm{~min}(36.7 \%, 53.3 \%$ and $50 \%)$ respectively.Circumference scarification, degree of water $\left(20^{\circ} \mathrm{C}\right.$ and $\left.60^{\circ} \mathrm{C}\right)$ duration (5 and 15 min respectively) had significant $(\mathrm{p}<0.05)$ effect on the seedling height $(16.03 \mathrm{~cm}, 13.85 \mathrm{~cm}$ and $12.87 \mathrm{~cm})$ respectively. Scarification along the circumference had significant $(\mathrm{p}<0.05)$ effect on the fresh and turgid weights $\left(7.65 \mathrm{~g}\right.$ and $7.67 \mathrm{~g}$ ) respectively while, $20^{\circ} \mathrm{C}$ and $40^{\circ} \mathrm{C}$ for 5 minutes had significantly $(\mathrm{p}<0.05)$ higher turgid weights $(4.97 \mathrm{~g}$ and $5.40 \mathrm{~g})$ respectively. $\odot$ JASEM
\end{abstract}

http://dx.doi.org/10.4314/jasem/v19i3.8

KEYWORDS: Pre-germination treatments, germination percentage, seedling vigour, Albizia zygia

\section{INTRODUCTION}

Albizia zygia(D.C. Macbr.) belonging to the family leguminosae-mimosideae is a medium to large tree, of over $50 \mathrm{~m}$ in height, can be classified as a longlived germinating tree which establishes under shade, and persisting into maturity (Hall and Swaine, 1981).Albizia zygia exhibits functional services such as erosion control, windbreak, provision of shelter, shade especially for coca trees plantation where it serve as a microclimate for degraded coca soil (Orwaet al., 2009;Anim-Kwapong and Teklehaimanot, 1995).Albizia zygia leaves are eaten as fodder byanimals and are consumed as vegetables(Eltahir and AbuReish, 2010) and used for the construction of buildings, handles of farming implements, and as timbers (Orwaet al., 2009).It has however being noted that leguminous seeds of some known Albizia species exhibit dormancy due to their hard impervious seed coats (Gunn, 1981). Hence, the need to research into effective technique of breaking dormancy by way of enhancing germination of seeds and their effect on seedling vigour of Albizia zygia.

\section{MATERIALS AND METHODS}

Albizia zygia seedlings raised from seeds were used for the study which was carried out at the nursery site of the Federal University of Agriculture Abeokuta.Germination percentage was measured by sowing 120 seeds each in germination boxes for two weeks for each pre-germination treatment and was calculated using

Germination Percentage $=$ Number of germinated seeds x 100 Number of Planted seed

Germinated seedlings were transplanted one per polypot, watered once in two days and seedling growth was measured two weeks after germination for twelve weeks. There were four replicates in each treatment. Mechanical scarification was carried out by comparing three methods of seed coat clipping namely: (a) clipped $2 \mathrm{~mm}$ from the micropyle (b) clipped $2 \mathrm{~mm}$ at the distal end and (c) clipped around the seed circumference. Treated were subsequently tested for germination and complete randomized design was used to analyze seedling growth.

Water treatment was carried to assess the effect of temperature and treatment timing on germination 
percentage and seedling growth. This was achieved by soaking seeds in water of $20^{\circ} \mathrm{C}, 40^{\circ} \mathrm{C}$ and $60^{\circ} \mathrm{C}$ for 5 minutes, 10 minutes, and 15 minutes respectively. Treated seeds were tested for germination percentage and, seedling growth measurement was analyzed using randomized complete block design. Sulphuric acid treatment was carried out to assess the effect of concentration and treatment timing on germination percentage and seedling growth by subjecting seeds to three levels concentrationsof $10 \%, 30 \%$ and $50 \%$ for 5 minutes, 10minutes, and 15 minutes respectively. Treated seeds were tested for germination percentage and, seedling growth measurement was analyzed using randomized complete block design.

Growth parameters measured are the leaf number, collar diameter, plant height, root to shoot weight ratio and root to shoot length ratio, fresh weight, dry weight, turgid weight and relative water content. The seedlings were harvested at 12 weeks old by careful removal of the ploythene bags while damage to the root and shoot were avoided. Relative water content (RWC) was determined by obtaining the fresh weight of the plants, after which the plants were immersed in water for 24 hours, the plants were removed, surface water was blotted-off and turgid weight was recorded. The same plants were oven dried at $100^{\circ} \mathrm{C}$ to a constant weight for 8 hours and the dried weight was recorded. It was calculated from the following equation (Turner, 1981):

RWC $=$ Fresh weight - Oven-dry weight $\quad$ x 100

Turgid weight - Oven-dry weight

\section{RESULTS AND DISCUSSION}

Pre-germination treatments effects on germination percentage of A. zygia seeds (Table 1).Germination percentage in mechanical scarification was highest in seeds scarified around the circumference at $36.6 \%$. Highest germination percentage of $53.3 \%$ was recorded in seeds treated for 5 minutes in $60^{\circ} \mathrm{C}$ water. In acid treated seeds, 50\% was recorded highest when treated in $50 \%$ concentration of acid for 15 minutes.It was revealed that mechanical scarification influenced some growth parameters measured from the seedlings that were raised (Table 2). Parameters such as seedling height $(16.03 \mathrm{~cm})$, fresh weight $(7.65 \mathrm{~g})$ and turgid weight $(7.68 \mathrm{~g})$ were significantly different $(\mathrm{p}<0.05)$ in seedling scarified around the circumference. The study shows also in Table 3 that water treatment (temperature and timing) had effect on some growth parameters. With this treatment, seedling height was significantly different $(\mathrm{p}<0.05)$ in seedlings treated in water at $20^{\circ} \mathrm{C}$ for 5 minutes with height $13.85 \mathrm{~cm}$ and $12.87 \mathrm{~cm}$ at $60^{\circ} \mathrm{Cfor} 15$ minutes while fresh, dry and turgid weights were influenced by $20^{\circ} \mathrm{C}$ and $40^{\circ} \mathrm{C}$. Fresh weight $(4.35 \mathrm{~g})$ and turgid weight $(4.98 \mathrm{~g})$ were significantly different $(\mathrm{p}<0.05)$ at $20^{\circ} \mathrm{C}$ for 5 minutes while dry weight $(1.73 \mathrm{~g})$ and turgid weight $(5.40 \mathrm{~g})$ were significantly $(\mathrm{p}<0.05)$ affected by $40^{\circ} \mathrm{C}$ for 5minutes. The effect of sulphuric acid treatment (concentration and timing) on the seedlings (Table 4)shows that all the parametersmeasured were not significantly different ( $p>0.05$ ) at $10 \%, 30 \%$ and $50 \%$ for 5 minutes, 10 minutes and 15 minutes respectively.

The highest germination percentage recorded for the mechanically scarified seeds around the circumference shows that the placement to cotyledon varies from one seed part to another and that the seed's embryo is close to the circumference part. This was in agreement with the results of Aduradola and Shinkafi 1999 that seeds of

Tamarindus indica scarified at the circumference recorded the highest germination percentage. The highest germination percentage found in seeds treated in water at $60^{\circ} \mathrm{C}$ for 5 minutes compared to others could be that the soaked seeds had more rupture of seed coat wall that allow water and air to permeate the tissues in order to enhance the physiological changes and the subsequent germination of the embryo according to Sabongari2001. This finding is similar to the contribution of Egharevba et al., 2005 that the seeds of Plukenetia conophorum produced better germination percentage when treated in $60^{\circ} \mathrm{C}$ of water. Also, optimum germination percentage found in seeds treated to $50 \%$ Sulphric acid for 15 minutes shows that dormancy breaking could be enhanced in this seed using $50 \%$ concentration of acid.The mechanical scarification done around the circumference influenced seedling height, fresh weight and turgid weight however, it was not significant on other parameters. The study demonstrated that seedling height had better performance than other parameters when treated in water at $20^{\circ} \mathrm{C}$ for 5 minutes and for 15 minutes in $60^{\circ} \mathrm{C}$. This is similar to the findings of Egharevbaet al., 2005 that seeds of Plukenetia conophorum treated to $60^{\circ} \mathrm{C}$ water produced better outcome on seedling height. The fresh weight and turgid weight of the seedlings were influenced in water of $20^{\circ} \mathrm{C}$ for 5 minutes while the turgid and dry weights were influenced by $40^{\circ} \mathrm{C}$ hot water at 5 minutes. These performances were probably due to stomata opening. All growth parameters measured Albizia zygia seedlings were not statistically influenced by any level of the acid concentrations and their timings. This outcome may be influenced by environmental factors. Though, the weight ratio of the root to shoot shows increased which is in the best interest of the

$$
\text { YISAU } U^{I}, J A ; A D U R A D O L A^{2}, A M ; A G B O O L A^{3}, D A ; J A Y E O L A^{4}, O A
$$


tree according to (Harris 1992) but was not statistically significant. This study concluded that the best pre-germination treatment that enhanced highest seeds germination of Albiziazygiawas $60^{\circ} \mathrm{C}$ hot water for seeds soaked for 5minutes compared to acid treatment or mechanical scarification. Where only purpose of pre-treatment is mechanical scarification and for growth development of seedling height, fresh weight and turgid weightseedlings raised from circumference scarified seeds were better than others at distal end and micropyle. This study also concluded that Albizia zygia growth performance and development that favours seedling height, fresh weight and turgid weight were derived from hot water treatment at $20^{\circ} \mathrm{C}$ for 5 minutes.

Table 1 Germination Percentage (\%) of Pre-treated seeds of Albizia zygia

\begin{tabular}{llll}
\hline $\begin{array}{l}\text { Mechanical } \\
\text { Scarification }\end{array}$ & Circumference & Distal end & Micropyle \\
& 36.7 & 15 & 22.5 \\
\hline Water/Time & 5 minutes & 10 minutes & 15 minutes \\
$20^{\circ} \mathrm{C}$ Water & 50 & 36.7 & 30 \\
$40^{\circ} \mathrm{C}$ Water & 13.3 & 30 & 43.3 \\
$60^{\circ} \mathrm{C}$ Water & 53.3 & 50 & 36.7 \\
\hline Acid/Time & & & \\
$10 \% \mathrm{H}_{2} \mathrm{SO}_{4}$ & 26.7 & 46.7 & 13.3 \\
$30 \% \mathrm{H}_{2} \mathrm{SO}_{4}$ & 46.7 & 43.3 & 20 \\
$50 \% \mathrm{H}_{2} \mathrm{SO}_{4}$ & 43.3 & 33.3 & 50 \\
\hline
\end{tabular}

Source: Laboratory work, 2012

Table 2 Effect of Mechanical Scarification on growth parameters of Albizia zygia seedlings

\begin{tabular}{|c|c|c|c|c|c|c|c|c|c|c|}
\hline $\begin{array}{l}\text { Treatment } \\
\text { type }\end{array}$ & $\begin{array}{l}\text { Scarification } \\
\text { site }\end{array}$ & Leaf No & $\begin{array}{l}\text { Plant Height } \\
\text { (cm) }\end{array}$ & $\begin{array}{l}\text { Collar } \\
\text { Diameter } \\
(\mathrm{cm})\end{array}$ & $\begin{array}{l}\text { Weight } \\
\text { Ratio }\end{array}$ & $\begin{array}{l}\text { Length } \\
\text { Ratio }\end{array}$ & $\begin{array}{l}\text { Fresh } \\
\text { weight }(g)\end{array}$ & $\begin{array}{l}\text { Dryweight } \\
\text { (g) }\end{array}$ & $\begin{array}{l}\text { Turgid } \\
\text { weight (g) }\end{array}$ & $\begin{array}{l}\text { Relative } \\
\text { Water } \\
\text { ontent }(\%)\end{array}$ \\
\hline $\begin{array}{l}\text { Mechanical } \\
\text { Scarification }\end{array}$ & Circumference & $13^{\mathrm{a}}$ & $16.03^{\mathrm{a}}$ & $1.99^{\mathrm{c}}$ & $3.11^{\mathrm{d}}$ & $1.39^{\mathrm{e}}$ & $7.65^{\mathrm{a}}$ & $1.65^{\mathrm{b}}$ & $7.68^{\mathrm{ab}}$ & $0.68^{\mathrm{c}}$ \\
\hline LSD 0.05 & $\begin{array}{l}\text { Distal end } \\
\text { Micropyle }\end{array}$ & $\begin{array}{l}14^{\mathrm{a}} \\
14^{\mathrm{a}}\end{array}$ & $\begin{array}{l}12.85^{\mathrm{b}} \\
13.75 \mathrm{~d}\end{array}$ & $\begin{array}{l}2.04^{\mathrm{c}} \\
2.04^{\mathrm{c}}\end{array}$ & $\begin{array}{l}2.84^{\mathrm{d}} \\
1.96^{\mathrm{d}}\end{array}$ & $\begin{array}{l}1.56^{\mathrm{e}} \\
1.94^{\mathrm{e}}\end{array}$ & $\begin{array}{l}5.55^{\mathrm{b}} \\
6.15^{\mathrm{d}}\end{array}$ & $\begin{array}{l}1.68^{\mathrm{b}} \\
1.78^{\mathrm{b}}\end{array}$ & $\begin{array}{l}6.13^{\mathrm{bc}} \\
6.50^{\mathrm{cd}}\end{array}$ & $\begin{array}{l}0.86^{\mathrm{c}} \\
0.92^{\mathrm{c}}\end{array}$ \\
\hline
\end{tabular}

Values with the same superscript along the same column are not significantly different (P>0.05). Values are means of treatment replicates.

Table 3 Response of growth parameters of Albizia zygia to Water Treatments

\begin{tabular}{|c|c|c|c|c|c|c|c|c|c|c|}
\hline $\begin{array}{l}\text { Water } \\
\text { temperature }\end{array}$ & $\begin{array}{l}\text { Time } \\
\text { (Minutes) }\end{array}$ & Leaf No & $\begin{array}{l}\text { Plant } \\
\text { Height } \\
(\mathrm{cm})\end{array}$ & $\begin{array}{l}\text { Collar } \\
\text { Diameter } \\
(\mathrm{cm})\end{array}$ & $\begin{array}{l}\text { Weight } \\
\text { Ratio }\end{array}$ & $\begin{array}{l}\text { Length } \\
\text { Ratio }\end{array}$ & $\begin{array}{l}\text { Fresh } \\
\text { weight } \\
(\mathrm{g})\end{array}$ & $\begin{array}{l}\text { Dry weight } \\
\text { (g) }\end{array}$ & $\begin{array}{l}\text { Turgid } \\
\text { weight (g) }\end{array}$ & $\begin{array}{l}\text { Relative Water } \\
\text { Content }(\%)\end{array}$ \\
\hline \multirow[t]{3}{*}{$20^{0} \mathrm{C}$} & 10 & $11^{\mathrm{a}}$ & $12.59^{\mathrm{ab}}$ & $2.21^{b}$ & $1.67^{\mathrm{d}}$ & $1.30^{\mathrm{e}}$ & $3.30^{\mathrm{a}}$ & $1.30^{\mathrm{b}}$ & $4.60^{\mathrm{ab}}$ & $0.58^{\mathrm{c}}$ \\
\hline & 15 & $10^{\mathrm{a}}$ & $12.53^{b c}$ & $1.88^{\mathrm{b}}$ & $2.53^{\mathrm{d}}$ & $1.73^{\mathrm{e}}$ & $2.60^{\mathrm{b}}$ & $1.45^{\mathrm{b}}$ & $3.50^{\mathrm{bc}}$ & $0.78^{\mathrm{c}}$ \\
\hline & 5 & $11^{\mathrm{a}}$ & $13.85^{\mathrm{cd}}$ & $2.01^{\mathrm{b}}$ & $1.52^{\mathrm{d}}$ & $1.55^{\mathrm{e}}$ & $4.35^{\mathrm{c}}$ & $1.55^{\mathrm{b}}$ & $4.98^{\mathrm{cd}}$ & $0.75^{\mathrm{c}}$ \\
\hline \multirow[t]{3}{*}{$40^{\circ} \mathrm{C}$} & 10 & $12 \mathrm{a}$ & $12.55^{\mathrm{e}}$ & $1.94^{\mathrm{b}}$ & $4.17^{\mathrm{c}}$ & $1.69^{\mathrm{d}}$ & $3.58^{\mathrm{a}}$ & $1.05^{\mathrm{a}}$ & $4.53^{\mathrm{ab}}$ & $0.72^{\mathrm{b}}$ \\
\hline & 15 & $12 \mathrm{a}$ & $12.35^{\mathrm{e}}$ & $2.00^{\mathrm{b}}$ & $3.12^{\mathrm{c}}$ & $1.67^{\mathrm{d}}$ & $3.73^{\mathrm{a}}$ & $1.40^{\mathrm{b}}$ & $3.93^{\mathrm{bc}}$ & $1.13^{\mathrm{b}}$ \\
\hline & 5 & $13 a$ & $11.33^{\mathrm{e}}$ & $1.98^{\mathrm{b}}$ & $2.22^{\mathrm{c}}$ & $1.32^{\mathrm{d}}$ & $4.73^{\mathrm{a}}$ & $1.73^{\mathrm{c}}$ & $5.40^{\mathrm{ac}}$ & $0.76^{\mathrm{b}}$ \\
\hline \multirow[t]{2}{*}{$60^{\circ} \mathrm{C}$} & 10 & $11 \mathrm{a}$ & $11.97^{\mathrm{ac}}$ & $1.80^{\mathrm{b}}$ & $2.31^{\mathrm{f}}$ & $1.57^{\mathrm{g}}$ & $3.63^{\mathrm{a}}$ & $1.08^{b}$ & $4.15^{\mathrm{c}}$ & $0.86^{\mathrm{e}}$ \\
\hline & 15 & $11 \mathrm{a}$ & $12.87^{\mathrm{cd}}$ & $1.94^{\mathrm{b}}$ & $2.34^{\mathrm{f}}$ & $1.15^{\mathrm{g}}$ & $4.90^{\mathrm{a}}$ & $1.48^{\mathrm{b}}$ & $5.03^{c}$ & $1.01^{\mathrm{e}}$ \\
\hline LSD 0.05 & 5 & $12 \mathrm{a}$ & $10.31^{\mathrm{ba}}$ & $1.79^{\mathrm{b}}$ & $2.74^{\mathrm{f}}$ & $1.79^{\mathrm{g}}$ & $4.18^{\mathrm{a}}$ & $1.20^{\mathrm{b}}$ & $4.48^{\mathrm{c}}$ & $1.02^{\mathrm{e}}$ \\
\hline
\end{tabular}

Values with the same superscript along the same column are not significantly different $(\mathrm{P}>0.05)$. Values are means of treatment replicates.

Table 4 Response of growth parameters of Albizia zygia seedlings to $\mathrm{H}_{2} \mathrm{SO}_{4}$ Treatments

\begin{tabular}{|c|c|c|c|c|c|c|c|c|c|c|}
\hline 6 & $\begin{array}{l}\text { Time } \\
\text { (Minute) }\end{array}$ & Leaf No & $\begin{array}{l}\text { Plant Height } \\
(\mathrm{cm})\end{array}$ & $\begin{array}{l}\text { Collar Diamete } \\
\mathrm{r}(\mathrm{cm})\end{array}$ & $\begin{array}{l}\text { Weight } \\
\text { Ratio }(g)\end{array}$ & $\begin{array}{l}\text { Length Ratio } \\
\text { (cm) }\end{array}$ & $\begin{array}{l}\text { Fresh weight } \\
\text { (g) }\end{array}$ & $\begin{array}{l}\text { Dry weight } \\
(\mathrm{g})\end{array}$ & $\begin{array}{l}\text { Turgid weight } \\
\text { (g) }\end{array}$ & $\begin{array}{l}\text { Relative Water } \\
\text { Content }(\%)\end{array}$ \\
\hline \multirow[t]{3}{*}{$10 \%$} & 10 & $11^{\mathrm{a}}$ & $11.87^{\mathrm{b}}$ & $1.96^{\mathrm{c}}$ & $1.52^{\mathrm{e}}$ & $1.21^{f}$ & $4.85^{\mathrm{a}}$ & $1.80^{\mathrm{b}}$ & $6.28^{\mathrm{c}}$ & $0.72^{\mathrm{d}}$ \\
\hline & 15 & $12^{\mathrm{a}}$ & $10.97^{\mathrm{b}}$ & $1.86^{\mathrm{c}}$ & $0.99^{\mathrm{e}}$ & $1.42^{\mathrm{f}}$ & $4.70^{\mathrm{a}}$ & $1.80^{\mathrm{b}}$ & $5.75^{\mathrm{c}}$ & $0.69^{d}$ \\
\hline & 5 & $11^{\mathrm{a}}$ & $10.66^{\mathrm{b}}$ & $1.87^{\mathrm{c}}$ & $1.77^{\mathrm{e}}$ & $1.58^{\mathrm{f}}$ & $4.05^{\mathrm{a}}$ & $1.55^{\mathrm{b}}$ & $5.15^{\mathrm{c}}$ & $0.67^{\mathrm{d}}$ \\
\hline \multirow[t]{3}{*}{$30 \%$} & 10 & $17^{\mathrm{a}}$ & $12.55^{\mathrm{b}}$ & $1.94^{\mathrm{c}}$ & $1.25^{\mathrm{e}}$ & $1.28^{\mathrm{f}}$ & $4.90^{\mathrm{a}}$ & $2.03^{\mathrm{b}}$ & $5.95^{\mathrm{c}}$ & $0.75^{\mathrm{d}}$ \\
\hline & 15 & $19^{\mathrm{a}}$ & $12.35^{\mathrm{b}}$ & $2.00^{\mathrm{c}}$ & $1.17^{\mathrm{e}}$ & $1.28^{\mathrm{f}}$ & $4.35^{\mathrm{a}}$ & $1.93^{\mathrm{b}}$ & $5.88^{\mathrm{c}}$ & $0.61^{\mathrm{d}}$ \\
\hline & 5 & $20^{\mathrm{a}}$ & $11.33^{\mathrm{b}}$ & $1.98^{\mathrm{c}}$ & $1.93^{\mathrm{e}}$ & $1.69^{\mathrm{f}}$ & $5.03^{\mathrm{a}}$ & $1.93^{\mathrm{b}}$ & $6.18^{c}$ & $0.73^{\mathrm{d}}$ \\
\hline \multirow[t]{2}{*}{$50 \%$} & 10 & $12^{\mathrm{a}}$ & $11.14^{\mathrm{b}}$ & $1.84^{\mathrm{c}}$ & $1.34^{\mathrm{e}}$ & $4.63^{\mathrm{f}}$ & $4.68^{\mathrm{a}}$ & $1.88^{\mathrm{b}}$ & $5.50^{\mathrm{c}}$ & $0.77^{\mathrm{d}}$ \\
\hline & 15 & $11^{\mathrm{a}}$ & $10.95^{\mathrm{b}}$ & $1.89^{\mathrm{c}}$ & $1.59^{\mathrm{e}}$ & $2.39^{f}$ & $5.20^{\mathrm{a}}$ & $2.08^{\mathrm{b}}$ & $6.60^{c}$ & $0.70^{\mathrm{d}}$ \\
\hline LSD & 5 & $12^{\mathrm{a}}$ & $11.57^{\mathrm{b}}$ & $1.83^{\mathrm{c}}$ & $1.48^{\mathrm{e}}$ & $3.44^{\mathrm{f}}$ & $4.85^{\mathrm{a}}$ & $1.78^{\mathrm{b}}$ & $6.23^{\mathrm{c}}$ & $0.68^{\mathrm{d}}$ \\
\hline 0.05 & & & & & & & & & & \\
\hline
\end{tabular}


Values with the same superscript along the same column are not significantly different $(\mathrm{P}>0.05)$.Values are means of treatment replicates.

\section{REFERENCES}

Aduradola, A.M. and Shinkafi, M.A., (1999): Germination Factors in seeds of Tamarindus indica Zuru Journal of Agriculture Vol. 1:1 and 2.

Anim-Kwapong, G. and Teklehaimanot, Z. (1995): Reclamation of degraded cocoa lands using Alibizia zygia (DC) Macbride. Land Degradation and Rehabilitation 6 (2): 109-123.

Egharevba, E.K., Ikatua, M.I. and Kalu, C. (2005): The influence of seed treatments and growing media on seedling growth and development of African walnut Plukenetia conophorum. African Journal of Biotechnology Vol. 4 (8), pp. 808811.

Eltahir, A.S. and AbuReish, B.I. (2010): Comparative morphological and anatomical studies of the barks of three Albizia species. Journal of Chemical and Pharmaceutical Research, 2(3):260-268.

Gunn, C.R. (1981): Seeds of leguminosae. Pp in 913925 in Polhill, R.M. and Ravens, P.H (eds).Advances in legumes systematics, Parts 1 and 2, Proceedings of the International Legume Conference, Kew, England.
Hall, J. B. and Swaine, M. D. (1981): Distribution and Ecology of vascular plant in a Tropical rainforest, Junk The Hague.

Harris, R.W. (1992): Root -Shoot Ratios. Journal of Aboriculture 18 (1)

Orwa, C. A., Mutua, K. R., Jamnadass, R. and Anthony, S. (2009): Agroforest tree Data-base: a tree reference and selection guide version 4.0 at http://www.worldagroforestry.org/sites/treedbs/tr eedatabases.asp.

Sabongari, S. (2001): Effect of Soaking duration on germination and seedling establishment of selected varieties of Tomato (Lycopersicum esculentum Mill). M.Sc. Thesis, Department of Biological Sciences, Usmanu Danfodiyo University, Sokoto, Nigeria

Turner, N., (1981): Techniques and experimental approaches for the measurement of plant water status. Plant Soil, 58, 339 - 366. 